DOI: 10.47750/jett.2021.12.01.016

\title{
Vandalism in castles, Tentors and the enhanced core of the historical Russian city
}

Natalia Nikolaevna Shelshakova ${ }^{1}$

\author{
Journal for Educators, Teachers and Trainers, Vol. 12 (1)
}

https://jett.labosfor.com/

Date of reception: 08 October 2020

Date of revision: 07 January 2021

Date of acceptance: 06 April 2021

Natalia Nikolaevna Shelshakova (2021). Vandalism in castles, Tentors and the enhanced core of the historical Russian city. Journal for Educators, Teachers and Trainers, Vol. 12(1). 123 - 131.

${ }^{1}$ Candidate of psychological sciences, docent, Petrozavodsk State University, Petrozavodsk, Russian Federation 


\title{
Journal for Educators, Teachers and Trainers, Vol. 12 (1) \\ ISSN 1989 - 9572 \\ https://jett.labosfor.com/
}

\author{
Vandalism in castles, Tentors and the enhanced core of the historical \\ Russian city \\ Natalia Nikolaevna Shelshakova ${ }^{1}$ \\ ${ }^{1}$ Candidate of psychological sciences, docent, Petrozavodsk State University, Petrozavodsk, Russian Federation
}

\begin{abstract}
The article describes the results of the work of the analytical department of an independent security system. The history of the creation of a criminal community at the state and regional levels is presented. The forms and types of work of the members of the criminal community are described. The article is based on an analysis of documents, anonymous sources, conversations with witnesses, self-reflection, etc. After the Second World War, people who, during the war, committed a number of war crimes against civilians by order of military commanders (redistribution of lands, redistribution of money resources, sexual crimes). This task was set thanks to the establishment of contacts with foreign agents who tortured concentration camp prisoners. The criminals released them on the condition of conducting terrorist actions against the Soviet people after the war (economy, social sphere, world order, etc.).
\end{abstract}

Keywords: recreation, crime, state, international relations, security services

\section{HISTORY}

The beginning of the work of the security services is associated with the name of Georgina Saxonskaya (mother of the future spouse of the heiress to the throne), who was a wealthy official, she owned real estate, grew up in an orphanage for children with mental retardation. As a teenager, she tied her fate with the cruel man Rothsch, who considered himself one of the best representatives of humanity, since he invented a sound-amplifying device that allowed dissenting to be destroyed without the use of physical violence: a microphone was placed in the ear and when the sound was amplified, the person told all the information about those who divulge classified information about the eminence.

Future husband of the heiress to the throne inherited the "wiretapping" system from his mother.

If you look deep into history, then from ancient times the Saxons (north) were associated with Prince Vladimir Monamakh (center), who headed the system of denunciations with the aim of uniting Russia and identifying loyal subjects to the tsar. Since then, the persecution of free-thinkers began.

Later intelligence services of the dominant kingdom set the task: the enslavement of the Russians, the corruption of the Russian soul, they also knew from the ancient scripture that the second coming of Christ might occur in Russia, at the same time, one of the dominant northern countries considered it impossible for a more powerful state to emerge than she.

A country that considers itself dominant took an active part in the murder of the royal family (the remains were not found). According to one version, Russian soldiers helped them escape to the north. Recreation could be handled by members of the security forces of the dominant kingdom, who helped the heir to the throne, who was in opposition to his mother, decided to preserve the clan and prepare relatives in a direct line for the development of Russia and the emergence of his new homeland- Russia. To this end, after the Second World War, spouse of the heiress to the throne of the dominant state implemented the idea of creating an English army of direct kinship: many actresses living in the USSR were under the control of the state security system, they underwent artificial insemination with the biological material of husband of the heiress to the throne. In the 1970s, "Patrusha" was already the governor of the ruling kingdom and watched the deterioration of the cultural, social climate in Russia. "Patrusha" (the governor of British intelligence) considered himself the king of all Russia and also knew that, according to ancient scriptures, the second birth of Christ should happen in Russia. Since they were orthodox believers (at the same time, it is difficult to apply this word to such people), the main feature was, since the 1960s, the extermination of Jews and persons of Caucasian nationalities in order to prevent the appearance of God on earth.

Based on this goal, the following crimes were organized and implemented:

1) After the Great Patriotic War, people who, during the war, committed a number of war crimes against the civilian population by order of the military commanders, were appointed to government posts at various 
levels in Russia (in addition to their direct responsibilities, during the Second World War they carried out the redistribution of land, the redistribution of financial resources, sexual crimes). This task was set due to the establishment of contacts with foreign agents who mocked the prisoners of concentration camps. The criminals released them on the condition of conducting terrorist actions against the Soviet people after the war (economy, social sphere, world order, etc.).

2) After the Great Patriotic War, a large number of orphanages were built, in which children born under the duress of the KGB were given. Women involved in art were close to power, some did not have the means of subsistence. Children were taken to orphanages, where they were taken by people with perverted sexual inclinations. Such orphanages were quickly closed by law enforcement officers, but by a strange coincidence, they were quickly opened, as it was controlled by the state. The state was the fiefdom of foreign agents who took part in the Great Patriotic War (the leading role was played by dominant kingdom ) [1, 3, 7].

3) Destruction of the Orthodox faith (poverty, disease, the impossibility of creating full-fledged relationships, etc.). At the same time, the renunciation occurred from the Almighty, although according to the ancient scriptures it is rare when people understood that the manifestation of God (a certain divine substance) is in every person, which is manifested in the phrase "Love your neighbor as yourself", do not educate as you see fit, do not teach, and above all love and understand the essence of what is happening in your neighbor. Therefore, the appearance of Jesus Christ on earth in the face of a man, with the flesh and blood of man, is only a confirmation of the manifestation of the divine essence in every ordinary person, while observing the commandments.

4) The destruction of science, the transfer of scientists to the West, where they were created unbearable conditions of existence according to the principle "There should be no heroes in Russia" or they were involved in secret terrorist developments. In this case, the cover of the Western special services was the former Russian citizenship of those whom they hired to commit the crime. Laws were passed that made it possible to defend dissertations with $90 \%$ plagiarism (folklore (chants, proverbs, etc.), lawmaking). Specialists from the special services worked in the Scopus and WS databases, who borrowed ideas from scientists' articles for free that were successfully implemented in the West and other parts of the world, while in Russia these developments did not receive recognition. $[2,3,4,7,8,9,10]$.

5) Violence against children in the education system (teachers were married to high-ranking local officials, so violence against children was unpunished).

6) Initiation in crime families has become a duty.

7) According to one of the versions, after the end of the Great Patriotic War, one of the allied countries had a condition: conducting the national economy and the economy in Russia, proceeding from the principle of cashing in "tsarist gold", which was bought out by the West and was spent on the needs of high-ranking officials (state support, services etc.). The citizens were workers in low-paid jobs. The elite of the dominant kingdom banned the printing of money not backed by gold. There was no business case. It was a whim of the elite of the dominant kingdom. The main slogan of foreign special services (mostly dominant kingdom) - Russia should never become a strong power.

8) At first, the prisoners of concentration camps were forced to agree with the condition of release and the conduct of underground work to destroy the Russian Federation, but later famous artists were not indifferent to the needs of people, they began to shoot wonderful films about love, honor, loyalty and other values of happy people who were filmed secretly in closed dachas.

9) By the 1960s, cities were secretly built in the outback of Russia, which the secret services of foreign states did not know about; ordinary people lived there who lived a happy Soviet life. This was done with the aim of ending the enslavement of Russia.

10) By the 1990s, the regions were ruled by thieves in law who controlled the activities of the special services of the Russian Federation (it was strictly forbidden to turn on internal wiretapping, so there were few suicides associated with this factor). Thieves in law controlled public order, there were no brutal contract killings, through video tracking, the crimes of maniacs were significantly reduced. However, the activities of the "thieves in law" were notable for their rigidity: all citizens in the city performed other functions: mistresses of the "masters" (high-ranking officials who were forced to marry by kinship, had mistresses), members of the faithful (pedophiles), the most humiliating was "sodomy" for material reward. In Pereyaslavl-Zalessky, in the family of a woman with mental retardation, there lived a boy with whom his mother led an asocial lifestyle. When he turned 14, he asked the thieves in law for permission to marry a woman. He was banned, because these "thieves in law" were a man with perverted sexual inclinations who controlled people, and this boy had to remain "homosexual". In 1998, in Pereyaslavl-Zalessky, then in the suburbs, a maniac Sanko (the future famous politician of world significance "Petrovich" or "Grandfather") appeared. He was distinguished by cruelty, cunning, on his conscience more than 600 corpses of young women and children, he raped his own people, confiscated valuables. As a result of such actions, he enriched himself. Then he attracted adolescents with mental retardation to this activity, and began to control adolescent "sexual services". Further, "Petrovich", who underwent treatment in a psychiatric hospital with the rape of a patient by a doctor, other patients with video 
filming, treatment with severe psychotropic drugs (treatment according to the methods of Gebels, which doctors mastered after the Great Patriotic War and were introduced to high-ranking positions in psychiatric hospitals in Russia). "Petrovich" has established cooperation with psychiatric hospitals, which reported maniacs who left the hospital under home supervision. Then, during the search activities, he was caught by "Patrusha", he learned that "Petrovich" had 20,000 maniacs distributed across the Moscow region, and they agreed that in the first in Russian history, a pedophile maniac would become a thief in law. He was appointed an overseer in Transcaucasia with the aim of eliminating the thieves in the law of Transcaucasia, who were "ordered" by the elder "thief in law" (father of "Royal". "Royal" did not know about his father's motives at that time.

"Petrovich" secretly arrived in the North Caucasus, where he killed and raped the children of thieves in law, poisoned with low-quality alcohol. This is how most of the children of the Caucasian diaspora were destroyed. This is how the first Russian-Caucasian war began. As a result, the thieves in the law of Transcaucasia rebelled, and an army of servicemen from R., which consisted of maniacs controlled by "Patrusha" and "Petrovich", came to them. This is how the first border garrison was created, which destroyed the main ancient families of Transcaucasia. Caucasian recruits were raped in the army in Caucasus for any insubordination to servicemen. Many servicemen were from families of thieves, into which, after initiations, relations with women no longer developed, so sodomy in the army was one of the spheres of satisfying the perverted needs of military leaders. In the army, the soldiers were given implants, and internal voice control was turned on. As a result, the first army of militants was formed, who were supposed to pacify Russian thieves in law. Thus, "Petrovich" curbed the old generation of thieves in law and his army was the militants created in the first Russian army in the Caucasus, then he was transferred to the State Security Committee of the Russian Federation. The main part of his army was soldiers from «White Russia» and Chechens, exhausted by violence and "internal voice control".

"Petrovich" joined the Russian security system with a forged passport, by his real name he is wanted as a serial maniac.

After the 1st Russo-Caucasian War, the military leader of the Chechen Republic. established connections with one of the powerful western countries, who had control of the internal voice accompaniment of Boris Nikolaevich Yeltsin, who was in power in Russia. His task was to remove him from his post, so the strange behavior of the President of the Russian Federation at receptions, alcoholism was a consequence of the execution of orders of internal voice control. When he realized that he could not cope with "Patrusha", was assigned "Petrovich".

According to the military registration and enlistment offices from abroad, an order was received for the destruction in the army, including of Russian-speaking recruits and military personnel, who were distinguished by kindness, good thoughts, lack of selfish intentions (violence, the inclusion of voice control, etc.). Caucasians ceased to be raped, because, due to active resistance (military operations on the territory of Russia), an agreement was reached with "Petrovich".

\section{WAR CRIMES IN R}

Leibmotif: the main trump card in the prevalence of military opposition was access to the equipment for internal voice support, which controlled the militants of Ch.R. The amplification of sound waves led to the complete subordination of the Caucasians to the Russian criminals-military commanders. During all wars, the main goal was to disconnect one or another criminal group from voice control.

1. Event: First Russian-Caucasian War. Leaders: "Patrusha", "Petrovich".

Countries: dominant kingdom (governor of one of the most powerful Western countries) - goal: Russians should not be strong. The security system of Russia (it has nothing to do with the head of state at that time) (governor of dominant kingdom) - the destruction of Russians (Orthodox) and Caucasians.

Defender: «Royal family». Goal: to end the killings of civilians and the rape of Caucasians.

Event: Head of Russia understood that due to the growth of crimes in Russia there were problems in the security system, he cooperated with S.-A and recommended to check the employee of "Petrovich", who, in the opinion of "Patrusha", was a "professional". "Petrovich" was already in touch with one of the powerful western countries, who felt that it was necessary to further promote the idea of destroying Russian (with the support of the dominant kingdom). "Petrovich" needed his own army, the Russian officers were on the side of Head of Russia. Then "Patrusha" and "Petrovich" made a decision to cordon off Chechen Republic, introduced persons with an unstable nervous system ("maniacs)" trained by "Petrovich" there, and orders from R. for committing terrorist acts began there. At first, it was explosions in the subway, houses, thieves in law of the old generation could not understand the reasons for the lack of opportunities to search for terrorists. The first terrorists, natives of Chechen Republic agreed to commit terrorist acts, since after serving in the army they already had "internal voice support", the territory of Chechen Republic was cordoned off by Russian "soldiers", and if the terrorist attack was not carried out, the entire Chechen family was destroyed.

2. Event: Second Russo-Caucasian War.

Forwards: "Patrusha", "Petrovich". 
Accomplice: "Royal" (goal: Caucasians were destroyed as a nation, which means that Caucasians must participate in the war of Russian Nazis against Russians as self-defense.

The aim of the attackers: the destruction of the Russian army, the best special forces, militia, etc. (contractors).

3. $\quad$ The coming of "Petrovich" to power - the order for "Royal" NordOst.

It was a planned operation by criminals led by "Petrovich" who came to power with fake passports. The main goal: the introduction of the troops of the "Royal" in Moscow. Chechen Diaspora began to control Moscow. Under this cover there was a complete removal of powers from the Russian "thieves in law". "Petrovich" with the participation of militants took control of Russia Prior to this crime, the militants were not allowed by the thief in law, who knew about the brutality of the militants, but had no idea about the true leader. With their help, "Petrovich" and "Patrusha" planned to destroy the family values of Russians, Orthodox traditions, since he had been a Nazi for a long time. He was fond of reading books on philosophy, history, and the appearance of the 2nd God on earth he did not need. According to the predictions in which all heads of state believed, the birth of Christ should take place in Russia. "Petrovich", having gained full influence in Russia, planned to seize European Union, dominant kingdom and become a world leader, which means, in his opinion, God.

According to one version, a large number of terrorist attacks on the territory of Russia occurred due to the reluctance of "Petrovich", "Visyakov" to turn off the internal voice accompaniment at a high frequency level, which was supplied to future militants in the Soviet army. Before each terrorist attack there was a warning from the militants: turn off the "ears", but "Patrusha", "Petrovich" refused, since their main goal was to destabilize the situation in the country, a complete transfer of powers from the state security system and the powers of thieves in law to "Petrovich".

New York Twin Towers attack.

During the visit of president of one of the most powerful Western countries to Russia, illegal actions were committed against him by the criminals who came to power in Russia, after that, implants were installed in the most powerful Western countries with the participation of "Pashinukha" with the voice message of terrorist organizations (Islamic State), as a result of which, having shown arrogance towards "Petrovich", a tragedy occurred in New York.

4. $\quad$ "Petrovich" - orders "Royal" - "Pashinukha" - Europe.

Since 1998, terrorist attacks began to take place in Europe, access was opened for illegal migrants (everything was based on international conventions on human rights), the number of sexual crimes increased, the culture of homosexualism and "free love" was forcibly introduced, etc.

Accomplices: Royal, Pashinukha (Islamic State is a terrorist organization, Irak).

5. $\quad$ "Petrovich" - orders "Royal", "Pashinukha" - world domination. In all these countries, the heads of state were subjected to violent actions by the Russia special services. The number of suicides rose sharply, drug trafficking, street prostitution, and so on increased. People with perverse sexual inclinations were appointed to high-ranking posts, who instilled a policy of debauchery and worship of violence.

6. Thanks to the special operation in the village from April 2019 to the present, all the leaders of the world-class gangs have been found and are under the control of the independent security service.

However, in the city of P. there are also criminals: "Patrusha", "Petrovich", "SS and family", "Meli Emelya", "Virus", "Adviser", "Visyakov"," Foka and family"," Fedor"," Gray"," Combination", who are trying to hide their crimes in April 2019 (organization and attempt to destroy an employee objectionable to the authorities), 2020-2021-hiding traces of crimes, daily day and night attempts to bring the same woman to suicide.

\section{REGIONAL ASPECT OF THE CIVIL WAR}

After the end of the Great Patriotic War, according to one version, the prisoners of the Wehrmacht concentration camps were released on the condition of organizing and conducting counter-terrorist operations in Russia), while they were appointed to high-ranking positions in all sectors of the economy and social sphere, they destroyed agriculture, committed violent actions against fellow citizens, stole children, led crime [1].

So in Karelia, such a leader of the criminal community was someone Visyakov. He established contacts with the nazis, who had long worked closely with dominant kingdom on the destruction of the country Russia «Visyakov» was a participant in the gang rapes and murders of adolescents, together with the cohabitant (Volokusha), they freely took the children of the orphanage, as he occupied a high position in the republic, together with her they filmed porn films, hid children in rented apartments.

«Visyakov» collaborated with servicemen "SS and family" and "Meli emelya", who in different years served in the Caucasus. There they committed violent actions against recruits and soldiers who were against the regime Russian military commanders, whose purpose was to destroy the Russian nation, namely, the corruption of men. "Visyakov" owned about 800 apartments in Petrozavodsk. Some of the apartments belonged to the "family business" couple. In Petrozavodsk, children for the "sex business" were supplied by "SS and Family", he was engaged in driving to suicide through an ear implant, eliminating business competitors (violence against relatives, threats, etc.). In the 1990s, in Petrozavodsk, these criminals began to lead crime according to the 
"Russian" principle: ordered crimes were planned by the criminal elite of the dominant kingdom and Russia authorities and distributed among the districts in order to worsen the psychological climate of Russians.

Since 2017, the situation in the region has deteriorated: a sharp increase in pedophilia, pornography, access to kindergartens, filming with hidden video cameras, terrorism, bringing children of selected cities by "foster parents", etc. Already the old thieves in law were under the control of the criminal security services, looking in the north-west of "Sedoy" and watching "SS and families" according to Karelia. All of them were approved by "Petrovich." All these criminal acts were headed by a criminal named "Risk". The main initiators of the above sexual crimes were: "Visyakov", "Volokusha", "Samin" (all over 70 years old).

After the Great Patriotic War, the prisoner of the Visyakov concentration camp gathered a gang of counterfeiters, rapists, formed families on the principle of a criminal with a criminal, where from an early age children entered into violent intimate relationships with their parents. Since 1968 "Visyakov" has raped young women in masks, then with his co-worker "Volokusha" they raped children from an orphanage, due to many factors their crimes became more cruel - children were raped and killed. At the same time, he has already taken up a high-ranking position in activities related to work with young people.

In the 1990s, being at an age, "Visyakov" began to prepare a shift for himself and his ranks got a child "Risk", he was committed sexual assault, then he was appointed chief of juvenile crime in the city. Children begged for money from foreigners, provided sexual services to high-ranking women.

So in one of the nightclubs of Petrozavodsk was opened a club of "lonely hearts" was opened, where members of a criminal group entered. Women came to the club, then children and adolescents of 12-14 years old joined them, who offered intimate services. The adolescents knew that in order to open a business, "Visyakov" demanded to satisfy high-ranking officials, the women of the criminal community knew about the age of adolescents and entered into intimate relationships with them. Criminals (women) held positions in state institutions, participated in corruption cases, how through the provision of sexual services the criminal community paid them for crimes. She was the head of this club "Mamulechka", which further by 2019 was held in many criminal cases as "Virus". She was the first to initiate children into the criminal business (the children should have been the first to visit her in order to provide sexual services), in case of refusals, she contacted "Visyakov", who then raped these children. Ordinary citizens trusted her, as she was trained as an actor, her main methods of manipulating the consciousness of good citizens were the voice and other indicators of nonverbal behavior.

In one criminal case of the rape of a teenager, "Virus" was accused: the teenager refused her, she complained to the leader of a criminal group, he was invited by "Visyakov", who raped him in front of witnesses (everyone was wearing masks). The parents filed an application with the prosecutor's office, which, thanks to A.V. Voronin, opened a criminal case against "Virus" and the masked criminals (ties with Moscow). "Visyakov" had connections with the prosecutor's office, asked one of the servants of the law to bring the case to one of the houses in the city center, where she went to visit relatives and leave it in the mailbox. While she was visiting, neighbors took the case, changed photos, testimonies of witnesses, etc. In this case, the teenagers were helped by A.V. Voronin. He knew about such a scheme of crimes and was able to change the forged documents for real ones again. As a result, the court presented a case with these protocols and video filming. "Virus" received a term. She did not betray her accomplices (perverts), so she received the key to high-ranking positions for the entire life.

Then "Virus" took a position in the city administration, in 2018 she was given permission to open a preschool institution without the appropriate documents, such institutions were not in the department of any ministry, respectively, they were private territory. Parents brought their children to this "kindergarten", and in the daytime people similar to their parents (pedophiles) came and took the children for "day walks", since the children were young and with implants, they could not inform their parents about what had happened. Such private non-existent houses ("kindergartens without documents") were under the cover of the state. In 2018 "Virus" resigned and was again hired for a high-ranking position in an educational institution. After leaving the city administration, she wanted to get a position in the institution in which soon, as the city's supervisors thought, the head was to be removed. The head of the institution was categorically against the appointment of "Virus", since for half a century he had resisted the bandit formations of "Visyakov", "Virus" and then "Riska". "Virus" got in touch with the overseer "Riskom" and her urgent desire to get into a leading position in the institution led to the destabilization of the situation in the city of Petrozavodsk in September 2018. Then they decided to put pressure on the head of the institution by destabilizing the situation in the city, which kept order in the city (he reissued state orders from true crimes to "fictional" ones, was engaged in the selection of foreign intelligence officers who protected the townspeople, searching for those who ordered the crimes and bringing them to justice). As a result, in September 2018, a maniac appeared in the city, there were many victims. The crimes were "ordered". The population was intimidated, the head of the institution understood the meaning of the crimes when he was told by the governor. As a result, "Virus" got a position in an educational institution.

As the city has become a closed territory since 2019, the criminals remained in their places, and networks of criminals of various orientations went out to them. 
Purge in the ranks of gangs in Russia, will lead to the spontaneous departure of such people in connection with the retirement age due to the awareness of the population of Petrozavodsk about the crimes of the top authorities, the above-mentioned people. The "Virus" remained in the settlement without losing a source of livelihood, since in connection with the understanding of the essence and consequences of the deed (accepting a kindergarten without documents - opening doors for pedophiles, child victims, participating in "lesbian" performances, violence against minors children and adolescents, the organization of group bullying, corruption, etc.), the fear that society is informed about her the crimes committed, with difficult living conditions in the far north - this is serving a life sentence.

\section{HISTORY OF ONE CITY}

Thanks to "Pashinukha" "Petrovich" began to look for those who, since 1978, secretly prevented ordered crimes, prevented terrorist attacks, reduced the number of victims during terrorist attacks, negotiated with the militants about an armistice bypassing "Petrovich". A world-class terrorist organization was beginning to understand that "government orders" in the regions of R. were not being implemented in full.

So in Petrozavodsk, instead of ordered crimes (murders, "sodomy"), staged "crimes" were committed according to the script (instead of violent "sodomy" young people were invited who voluntarily played these scenes for a monetary reward, instead of murders for hire, the corpses of homeless citizens were brought, who died and were not claimed by their relatives. All contract crimes were prevented until "Petrovich" found out about it upon arrival in this city in March 2019. The official meeting took place in the "Hot spot" " university, where he was met by a representative of the institute connected with the rule of law and handed over to the chief manager of criminal state "orders" information that ordered crimes in the city of Petrozavodsk were not committed. The main goal of this "citizen" was to obtain a high post and women's revenge on a person who was engaged in these staged scenarios for the good of the homeland and protecting the population from criminals on a national scale. He was already poisoned with clonidine (tea, sleeping pills). This was done by the recently arrived from the far north "Zaklepka". Since his arrival, the people of "Pashinukha" (Island state) have established ties with the city, so since 2014, criminals have had free access to clonidine and other prohibited drugs.

Further, "Petrovich" in 2019 began to observe this city and found out that it is in it that a person lives (a woman, up to 40 years old), who actively participates in investigations of various types of crimes from corruption to terrorist attacks, analyzes information, and the search for criminals was carried out instantly (at that time she had no relation to law enforcement). The special services received valuable information for law enforcement through the "impalant", which the woman did not know about until 2019.

As a result, in March 2019, a woman was found, and "Petrovich" was ordered to eliminate this human.

The plan was as follows:

1. Poisoning by means of gas "newbie" (connection at night through heating equipment, which gradually leads to a complete loss of consciousness). Food poisoning.

2. Gathering of regional "thieves in law", most of whom held high-ranking positions on guard of order (FSB, police, Ministry of Emergency Situations, medicine). They accepted the order of the governor ("Patrusha", "Petrovich") to destroy this woman. At night they opened the ventilation pipes and supplied a poisonous substance - "novice" gas. The woman felt unwell, the child's condition deteriorated sharply, she began to call hospitals, there was no connection. According to the results of a medical examination, after poisoning by a "novice" and a night operation, all internal organs of the woman were burned, which was shown by endoscopy. After 2 weeks of sick leave, the woman under the control of the "implant" after the anti-terrorist operation went to work, as the operation continued. There were "heroes" who tried to put on the image of the saviors of the city, but during the examination it was established that such a defeat of internal organs, only one person.

Some of the residents of the city were evacuated, the rest participated in the organization of the crime or remained in the city or suburbs as relatives (watching "SS and family", "Foka and family", watching "Old" and "Combination", " Meli Emelya», "Guber" all law enforcement officers (FSB, police, medicine, Ministry of Emergency Situations, thieves in law, overseers) under the leadership of "Petrovich" and "Patrusha" participated in the destruction of this woman. Some refused to participate, paid tribute to the beholder and left the city. There are 600 people left in the city.

At the time of April 3-10, there was no longer a single person on duty in the city, all the guards were preparing for a special operation to destroy a woman in P. Later, they told their relatives about their active participation in the liberation of the city, received awards, promotions in ranks and positions, while they all mocked the woman for two weeks in April 2019, and then until the situation stabilized (the arrival of peacekeeping forces of world significance).

After April 10, colleagues from Murmansk came to the rescue. The city of Petrozavodsk had nothing to do with this.

3. Connecting a citizen with an internal voice accompaniment: "registration in a prison". 
4. Organization of the anti-terrorist operation "night watch", the collection of terrorists who were preparing terrorist attacks throughout the territory of Russia. The citizen received then (according to the terrorists) the name "witch", since the policeman Kolokoltsov who joined in, and everyone who was against the regime of "Petrovich" and "Patrusha" already guarded the house, and when approaching the house, they were rendered harmless.

5. $\quad$ Continuation of the operation (collection of "gasmen", hired killers, maniacs).

6. After the completion of the 2-week April operation, the top authorities in P. were informed that the woman had been liquidated, she was replaced by an "actress". The information was false, the woman remained alive, did not hide, went to work, as she understood that she was an employee who unmistakably determines the authenticity of personalities and documents, reveals schemes of crimes with participants, determines the measure of their complicity, which was necessary to search for networks of criminals who for half a century, as well as 2 weeks, terrorized Russia and, in particular, the city of Petrozavodsk ("Visyakov", "Risk", "Sovetnik", "Volokusha", etc. returned to the city. who kept in Petrozavodsk a network of dens, pornographers, etc.). The woman was not replaced, since by wiretapping it was possible to immediately determine the authenticity of the person.

7. "Petrovich", "Patrusha", "Visyakov", " Sovetnik " gave instructions to bring the "actress" to suicide, as it were.

For a year and a half, through internal voice support, intelligence officers (80 countries participated) day and night (using sound effects on the street and at home, using the Internet, an implant, etc.) were driven to suicide. The leader was in Petrozavodsk "SS and Family". Gradually the criminals were disconnected, but were already under the control of "Patrusha", "Royal" and policeman Kolokoltsov, who provided protection and neutralization of the criminals.

8. Local criminals, who continued their work, remained in their posts, some were replaced by similar people. They received a salary for driving a woman to suicide ("Foka and the Family»,"Fedor", "Old", "R-st", "Virus", "Visyakov", "SS and Family", etc.).

9. "SS and Family" had direct contacts with "Petrovich".

"SS and Family" implemented the following types of incitement to suicide in order to form Orthodox consciousness:

- at night after a day of listening to insults with an internal implant, decrees on the need to reeducate into a herd being, the woman said at night that she did not believe in God, they began to hit her on the head and stomach with electromagnetic waves, after 5 minutes of pain, the woman admitted that God exists.

- connection through the implant of smells of alcohol, urine, to compromise a woman.

- relatives of criminals from 2019 to 2021 received preferences at the place of work (in the form of bonuses, improvement of offices, equipment, etc.).

- In May 2020, young people entered the city (it was an army of many thousands of "Petrovich's" blood children, who were brought up in the image and type of a father in G-ii con camp): maniacs, murderers, "bullingers", etc.

- parting with a loved one, since through a voice implant, the criminal group "SS and Family" knocked out the image of the woman he loved in the same way.

"SS and family" is not related to the creation of a security system, the demonstration of this family's ties with "Petrovich", "Patrusha" is a factor of influence on citizens, thereby trying to remain significant people in the city after the publication of the violations of these security guards. In the Kremlin, there is no "Petrovich"for a long time, there are photos on websites, a similar face in the TV, he is clearly under the control of an independent security system. In the country, the system of employees begins to work clearly in accordance with the job description, social support, the health system has been established, the checks in the security system of the police, the Ministry of Emergency Situations are ending, corrupt officials are leaving, the food bases are fully debugged and checked.

A woman who was "ordered" by the top authorities of the Russia has information and methods of searching for suicide bombers, maniacs, contract killers, reveals schemes of crimes of various directions, so "Petrovich", " Patrusha " and was given the task of" SS and family " and their accomplices (local security services, police, etc.) about the need to destroy the woman. A woman who is not a member of the military and other security systems), a security system was created, which local criminals recorded and began to implement it under the leadership of "SS and Family", "Patrusha", "Foki and Family".

The bullying of the woman from 2019-2021, her persistence, the inability to bring her "wiretapping", intimidation led to the surrender of their accomplices by the bandits. In the balance on one side was the life of a woman (or her suicide), on the other side was the transfer of bandits to already verified employees of an independent security system. Since the woman did not give up and survived, by 2021, all the tops of the gangs were under the control of an independent security system.

The security system in its present form reveals the essence of the universe, gives an understanding of love and faith in God and human. Since a woman does not issue a security system in print, law enforcement officers who 
participated in a terrorist operation on the side of criminals and remain in the workplace can be especially dangerous criminals (local prosecutor's office, FSB) [5, 6].

\section{REFERENCES}

1. "The Constitution of the Russian Federation" (adopted by popular vote on 12.12.1993) (taking into account the amendments introduced by the Laws of the Russian Federation on amendments to the Constitution of the Russian Federation dated 30.12.2008 № 6-FKZ, dated 30.12.2008 № 7-FKZ) // "Collected Legislation of the Russian Federation ", 26.01.2009, № 4, Art. 445.

2. Ikonnikova G.I. Filosofiya prava. - M.: Yurayt, 2010. - 351 p.

3. Leyst O.E. Sushchnost' prava. - M.: Zertsalo-M,2011. - 352 p.

4. Matuzov N.I., Mal'ko A.V. Teoriya gosudarstva i prava. - M.: Delo, 2011. - 528 p.

5. Naumov A.V. Rossiyskoye ugolovnoye pravo. V 3 tomakh. Volume 2. Osobennaya chast'. Chapters 1-10. - M.: Wolters Kluwer, 2010. - 504 p.

6. Nersesyants V. Problemy obshchey teorii prava i gosudarstva. - M.: Infra-M, 2010 - 816 p.

7. Rassolov M.M., Malakhov V.P., Ivanov A.A. Aktual'nyye problemy teorii gosudarstva i prava. M.: Yuniti-Dana, 2010. - 448 p.

8. Teoriya gosudarstva i prava / Ed. A.S. Pigolkina, YU.A. Dmitriyeva. - M.: Yurayt, 2011. - 752 p.

9. Ugolovnoye pravo Rossii. Chasti Obshchaya i Osobennaya / Pod red. A.V. Brilliantova. - M.: Prospekt, 2010. - $1232 \mathrm{p}$.

10. Yaroshenko O.P. Murder committed in a state of passion, especially qualifications // Rossiyskiy sledovatel'. - 2011. - № 5. - P. 18 - 21. 